\title{
Sclerotherapy as treatment of lingual hemangioma: clinical case report
}

\author{
Escleroterapia como tratamento de hemangioma lingual: \\ relato de caso clínico
}

\author{
Mirlany Mendes Maciel OLIVEIRA' ${ }^{1}$ 0000-0002-4744-8094 \\ Bruno Araújo da SILVA² iD 0000-0002-8493-5852
}

\begin{abstract}
Hemangioma is a benign neoplasm characterized by abnormal proliferation of blood vessels. It is mainly located in the head and neck region, especially in the tongue, jugal mucosa, and lips. The main complaints of patients concern esthetic and functional issues, and the diagnosis is made through clinical examination and semio-technical maneuvers. Hemangioma has a wide range of treatment options, and there should be an individual analysis of each case for a more efficient therapeutic choice. Sclerotherapy as a treatment method for hemangioma provides a noninvasive, low cost intervention with satisfactory resolution in a short period of time. The aim of this study is to present the case of a hemangioma with 20 years of evolution, located in the lingual body region in a hypertensive patient, treated with sclerotherapy using the $5 \%$ ethanolamine oleate sclerosing agent, with total regression of the lesion. The sclerotherapy in this case was an efficient treatment modality. Through a non-surgical procedure and in a short period of time there was total remission of the lesion.
\end{abstract}

Indexing terms: Hypertension. Neoplasms. Sclerotherapy.

\section{RESUMO}

O hemangioma é uma neoplasia benigna caracterizada por proliferação anormal dos vasos sanguíneos. Está localizado principalmente na região da cabeça e pescoço, principalmente na língua, mucosa jugal e lábios. As principais queixas dos pacientes referem-se a questões estéticas e funcionais, e o diagnóstico é feito por meio de exame clínico e manobras semi-técnicas. O hemangioma possui uma ampla gama de opções de tratamento e deve haver uma análise individual de cada caso para uma escolha terapêutica mais eficiente. A escleroterapia como método de tratamento do hemangioma fornece uma intervenção não invasiva e de baixo custo, com resolução satisfatória em um curto período de tempo. O objetivo deste estudo é apresentar o caso de um hemangioma com 20 anos de evolução, localizado na região do corpo lingual em um paciente hipertenso, tratado com escleroterapia utilizando o agente esclerosante de oleato de etanolamina a 5\%, com regressão total da lesão. A escleroterapia nesse caso foi uma modalidade de tratamento eficiente. Através de procedimento não cirúrgico e em curto período de tempo houve remissão total da lesão.

Termos de indexação: Hipertensão. Neoplasias. Escleroterapia.

$\boldsymbol{\nabla} \nabla \nabla \nabla$

1 Universidade Federal de Uberlândia, Departamento de Cirurgia e Traumatologia Buco-Maxilo-Facial e Implantodontia. Uberlândia, MG, Brasil.

2 Hospital Geral de Roraima, Departamento de Cirurgia e Traumatologia Buco-Maxilo-Facial. Av. Brigadeiro Eduardo Gomes, 1364, Aeroporto, Boa Vista, RR, Brasil. Correspondence to: BA SILVA. E-mail: <araujoodontologia@gmail.com>.

$\boldsymbol{\nabla} \mathbf{v} \boldsymbol{v}$

How to cite this article

Oliveira MMM, Silva BA. Sclerotherapy as treatment of lingual hemangioma: clinical case report. RGO, Rev Gaúch Odontol. 2020;68:e20200017. http://dx.doi.org/10.1590/1981-86372020000173654 


\section{INTRODUCTION}

Hemangioma is a benign neoplasm originating from endothelial cells, characterized by abnormal proliferation of blood vessels. It has rapid growth, and there can be a slow regression phase until total regression $[1,2]$.

The hemangioma has uncertain etiology; it may have a congenital or traumatic origin. It is generally asymptomatic, but it is not uncommon to be associated with pain, bleeding, ulceration, secondary infections, and large facial asymmetries [3].

It is most commonly located in the head and neck region, which represent $60 \%$ of the cases. In the maxillofacial region, it most frequently affects the lips, tongue, and jugal mucosa $[2,4]$.

In clinical examination, the hemangioma usually presents as a stain or nodule of a color that varies from red to purple, depending on the location and depth of the tumor [5]. This pathology can be classified as superficial, deep, or mixed. Superficial hemangiomas are located in the superficial dermis; deep hemangiomas are located in the reticular and/or subcutaneous dermis; and mixed hemangiomas have a superficial and deep component [6].

In most cases the diagnosis is made through the patient's clinical history and clinical examination. The use of semio-technical maneuvers such as fine-needle aspiration biopsy and, most importantly, diascopy, is essential. These lead to a simple and conclusive diagnosis of the lesion, since incisional biopsy presents risks of hemorrhage [7-9].

According to the American Academy of Dermatology, the hemangioma treatment should have 5 main goals: to prevent complications, to prevent permanent deformation, to minimize psychosocial distress, to avoid aggressive procedures, and to minimize scarring, infection, or pain [10].

The therapeutic management for hemangioma depends on its classification and location, and includes radiotherapy, electrocoagulation, laser application, cryotherapy, embolization, surgery, sclerotherapy, and interferon administration [3].

Sclerotherapy is a conservative, low invasive, effective, low cost technique that can achieve favorable clinical and esthetic results in a short period of time $[8,9]$.
The aim of this study is to present the case of a male patient with hemangioma in the lingual body region, treated by injection of a monoethanolamine oleate sclerosing solution, with total remission of the lesion.

\section{CASE REPORT}

A 40-year-old black male hypertensive patient presented at the Center of Dental Specialties of the State of Roraima with a major complaint of "a lump in the mouth" that caused self-esteem and phonetic problems.

The intra-oral clinical examination revealed a lesion composed of a purplish tumor mass with sessile base, smooth surface, and resilient to palpation, approximately $6 \mathrm{~cm}$ long, located in the lingual body, with a history of evolution of approximately 20 years after accidental bite. Patient reported that he had previously sought help, but the consulted professionals were clueless about the problem (figure 1).

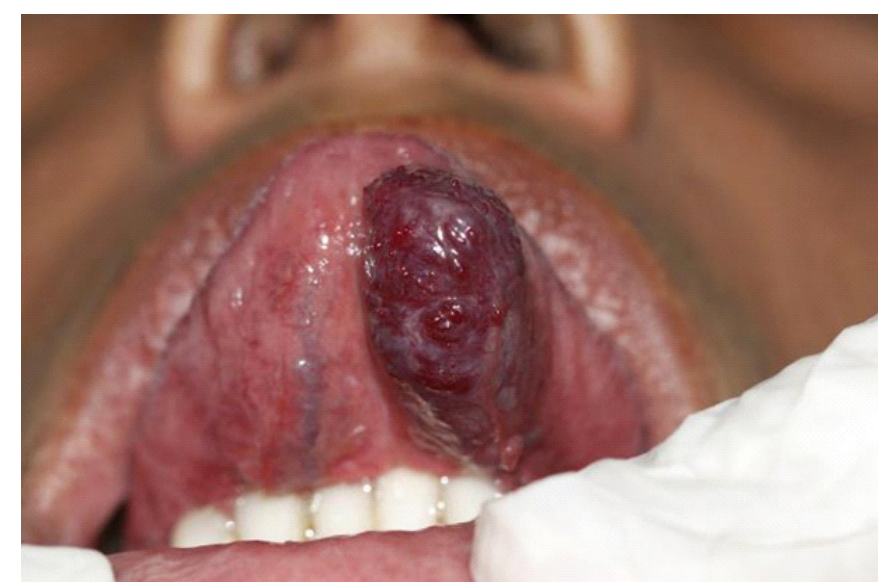

Figure 1. Initial aspect.

Under diascopy, ischemia was observed. Due to the presence of blood collection in the interior of the lesion, the diagnostic hypothesis of hemangioma was considered (figure 2).

Due to the esthetic and functional impairment and in order to minimize the risk of hemorrhage, sclerotherapy with the $5 \%$ ethanolamine oleate sclerosing agent was used. This agent first acts by irritating the endothelial intima of the vein, producing a sterile inflammatory response that leads to fibrosis of the vascular wall. 


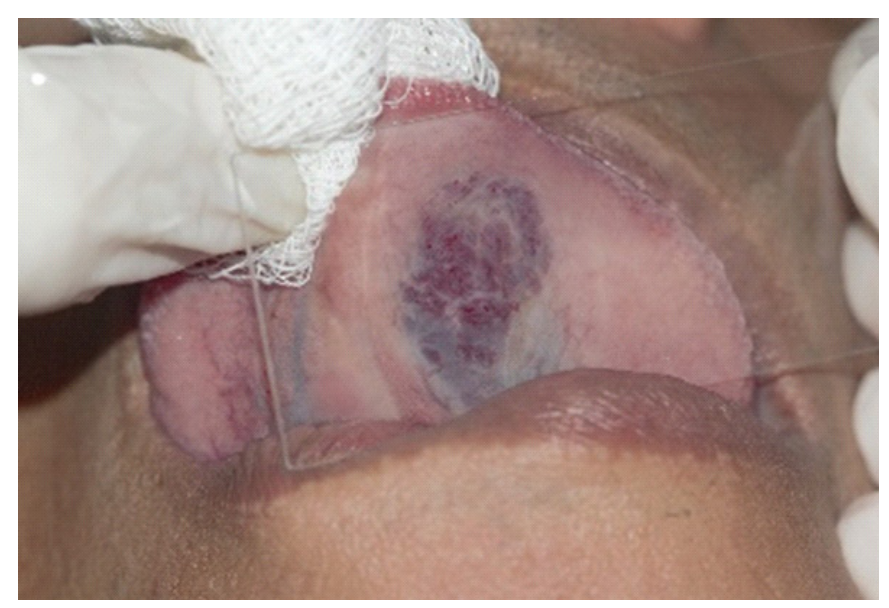

Figure 2. Diascopy.

A differentiated technique was used. Local anesthesia was performed using 3\% mepivacaine without vasoconstrictor, and concomitantly $2 \mathrm{ml}$ of $5 \%$ ethanolamine oleate was injected into the deeper portion of the lesion. Previously, aspiration was performed, aiming to minimize the number of needle punctures in the lesion to avoid bleeding, concomitantly using the properties of the local anesthetics without vasoconstrictor and of the ethanolamine oleate, in order to provide greater comfort to the patient during and after the applications and more satisfactory results. The patient did not report any uncomfortable sensation during the application.

In the post-therapy visit (7 days after), the patient reported having felt burning in the region, and the lesion was clinically ulcerated, with a necrotic surface in the lingual body region. The regression and the decrease in the color intensity of the lesion were quite evident. In this session, the amount of solution was reduced and the technique used was the same, and $0.7 \mathrm{ml}$ of the solution associated with the local anesthetic 3\% mepivacaine without vasoconstrictor was administered in the deepest region of the lesion. The patient was prescribed local applications of triamcinolone $1 \mathrm{mg} / \mathrm{g}$ every 8 hours (figure 3).

Fourteen days after the first application, significant regression of the lesion was observed, with almost total decrease of the ulcerated area and decrease of the patient's symptomatology. Two milliliters of ethanolamine oleate associated with $1 \mathrm{ml}$ of $3 \%$ mepivacaine without vasoconstrictor was applied (figure 4).

Twenty-one days after the start of treatment, the patient presented regression of approximately $2 / 3$ of the lesion, and an additional application of $2 \mathrm{ml}$ of $5 \%$ ethanolamine oleate associated with 3\% mepivacaine without vasoconstrictor was performed. Proservation of 14 days after the last application was performed.

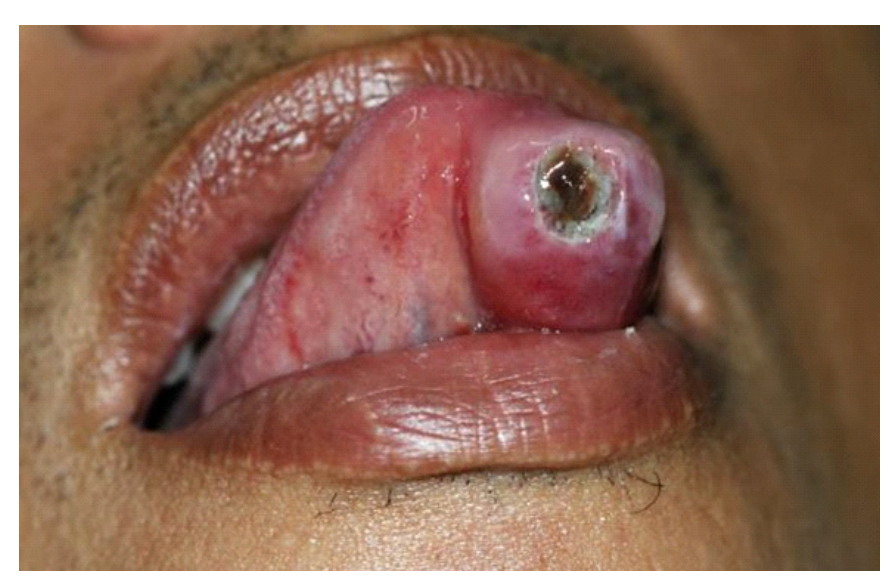

Figure 3. Ulcerated lesion (7 days).

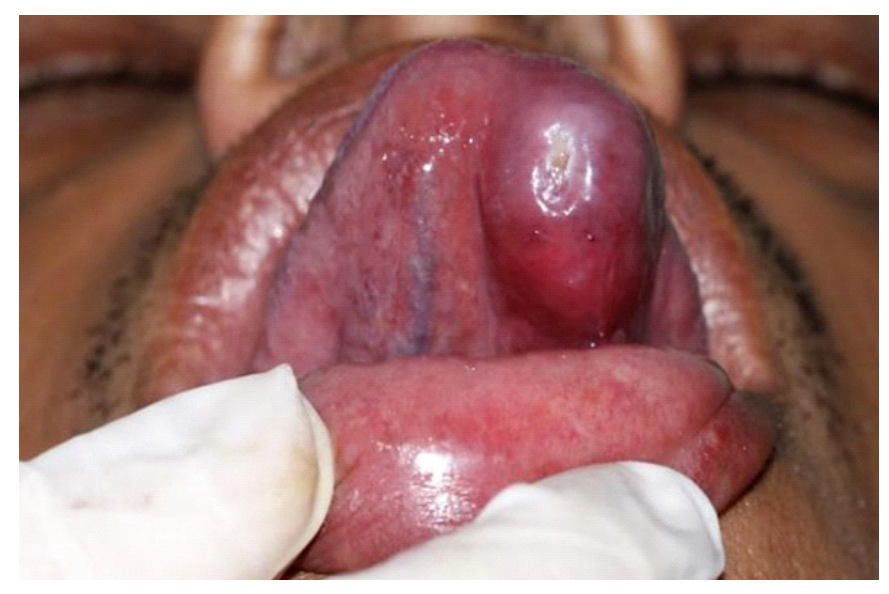

Figure 4. Regression of ulcerated lesion.

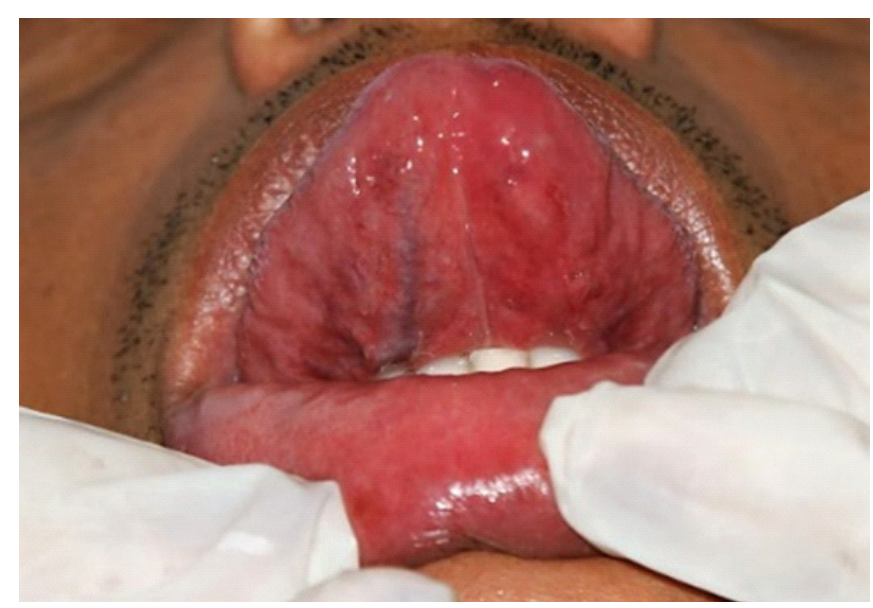

Figure 5. Two months of preservation. 
After 35 days of treatment, the region where the hemangioma was approximately $6 \mathrm{~cm}$ long had regressed almost completely. After 2 months of proservation, the lesion had completely regressed. The patient had no pain complaints and the esthetic and functional aspects were satisfactory (figure 5).

\section{DISCUSSION}

Currently, the hemangioma has several forms of treatment. The different materials and techniques used have as main objective the extinction of the tumor mass.

Sclerotherapy is a low-cost, easy-to-perform method that provides effective functional and esthetic results, promoting, in many cases, reduction of the lesion without the need for a surgical procedure [11].

Vascular lesions should be properly diagnosed through semio-technical maneuvers and complementary tests. Diascopy is a semio-technical maneuver of great relevance for the differential diagnosis of this lesion.

The local anesthetic used in this case is controversial in the literature. Authors such as Wang et al. [12] and Zanettini et al. [13] state that there is no need for the use of anesthetic because the burning sensation of the medication is felt even under local anesthesia. Such symptom was not reported by the patient of this case report during the application.

The present case contradicts the study by Chinen et al. [14], who found that in a sample of 235 cases of oral hemangiomas, $90 \%$ of the cases had a one-year evolution time. In this case, the hemangioma was present for 20 years, and in the literature there are case reports of oral hemangiomas with 42 and 53 years of evolution time $[3,9]$. During all these years, our patient sought professional help, but the consulted professionals did not make a conclusive diagnosis. Due to the size of the lesions, the patient had changes in occlusal aspects, such as the presence of wear on the incisal edges of the lower incisors in the region corresponding to the lingual contact.

The action mechanism of the ethanolamine oleate sclerosing agent is based on tissue necrosis of the region where it is applied, associated with the formation of local thrombi, usually observed 24 hours after application. It also has hemostatic function because it is derived from oleic acid $[12,14]$.
In order to determine the type of hemangioma treatment, some issues should be taken into account, such as size, location, and duration of the lesion, the hemodynamics of the lesion, the viability of the technique to be used, and personal characteristics of the patient, such as age and systemic conditions [12,14].

Injection of the medication should be performed in the deepest region of the lesion to avoid undesired mucosal necrosis ${ }^{3}$. In the case presented, it was observed that even though the injection was administered in the central and deepest region of the lesion, necrosis occurred. It was then treated with triamcinolone $1 \mathrm{mg} / \mathrm{g}$ every 8 hours, with full regression after 7 days of use.

The sclerotherapy technique is contraindicated in cases of uncontrolled diabetic patients and in sites of secondary infection. The use of ethanolamine oleate should be avoided during pregnancy due to possible iatrogenic effects $[3,12]$.

The dose of the medication should be proportional to the size of the lesion and applied every seven days, not exceeding $2 \mathrm{ml}$ per session [3].

In the literature, there is currently little knowledge about the treatment of oral hemangiomas with the use of sclerosing agents in hypertensive patients. However, according to Sukigara et al. [15], the dissemination of the drug can occur when it reaches the interior of the blood vessels, but does not cause greater complications. However, during appointments with hypertensive patients, the patient's blood pressure should be checked prior to initiation of the procedure. The professional should reassure the patient and monitor the patient's reactions during the application of the medication, in order to minimize the risk of medical emergencies.

For treating vascular lesions, especially hemangiomas, it is fundamental that the dental surgeon have knowledge about blood vessel pathologies, diagnostic methods, the different treatment methods and their indications and contraindications, and management of complications. If the dental surgeon does not feel able to perform the hemangioma treatment and thus restore the function and esthetics of the affected region, it is important that they refer the patient to the maxillofacial surgeon.

\section{CONCLUSION}

Sclerotherapy is a well-accepted technique for the treatment of oral hemangiomas. It is an effective, easy-to- 
apply, non-invasive, low-cost therapeutic option that has a lower risk of hemorrhage and reduced surgical trauma.

It is important that the dental surgeon self-assess their qualification for the management of hemangioma treatment, and have the knowledge of the medication that should be used in sclerotherapy treatment. The professional should be prepared for the management of healthy patients and of those with physiological changes, to avoid the occurrence of medical emergencies associated with the procedure. If there are medical emergencies, the professional should be prepared to provide the initial assistance.

\section{Collaborators}

MMM Oliveira, idealization of the study, intellectual contribution and corresponding author. BA Silva, idealization of the study, review of writing and final formatting of the article.

\section{REFERENCES}

1. Corrêa PH, Nunes LCC, Johann ACBR, Aguiar MCF, Gomez RS, Mesquita RA. Prevalence of oral hemangioma, vascular malformation and varix in a Brazilian population. Braz Oral Res. 2007;21(1)40-45. https://doi.org/10.1590/S1806-8324 2007000100007

2. Neville BW, Damm DD, Allen CM, Bouquot JE. Patologia oral e maxilofacial. $3^{a}$ ed. Rio de Janeiro: Guanabara-Koogan; 2009.

3. Ribas MO, Laranjeira J, Sousa MH. Hemangioma bucal: escleroterapia com oleato de etanolamina. Revisão da literatura e apresentação de caso. Rev Clín Pesq Odontol. 2004;1(2):31-36. https://doi.org/10.1590/jvb.2014.035

4. Assis GM, Silva SRP, Moraes PH, Amaral JIQ, Germano AR. Hemangioma de Lingua: Relato de caso. Rev Cir Traumatol Buco-Maxilo-Fac. 2009;9(2)59-66.
5. Palma FR, Garcia JAC, Jung R, Garcia RN, Aranha FCS. Escleroterapia de hemangioma oral. Relato de caso. Salusvita, 2016;35(1)85-93.

6. Garzon MC, Enjolras O, Frieden IJ. Vascular tumors and vascular malformations: Evidence for an association. J Am Acad Dermatol. 2000;42:275-9. https://doi.org/10.1016/S0 190-9622(00)90138-5

7. Cruz FLG. Diagnóstico diferencial de hemangioma por meio da vitropressão. RGO, Rev Gaúch Odontol. 2011;59(1)125-129.

8. Mandú ALC, Lira CRS, Barbosa LM, Silva VCR, Cardoso OJA. Escleroterapia de hemangioma: relato de caso. Rev Cir Traumatol Buco-Maxilo-facial. 2013;13(1)71-76.

9. Rocha ABM, Sant'anna FB, Fernandes IS, Azoubel E, Araujo, RPCA. Escleroterapia de hemangioma em borda lateral de língua: relato de caso. Rev Ciênc Méd Biol. 2014;(3):398-402. http://dx.doi.org/10.9771/cmbio.v13i3.12927

10. Cardoso CL, Fernandes LMPSR, Rocha FR, Gonçalves ES, Junior OF, Taveira LAA. Abordagem cirúrgica de hemangioma intraoral. Odonto Clin.-Cient. 2010;9(2)177-180.

11. Almeida AC, Camargo WR. Hemangioma bucal tratamentos preconizados. Braz J Surg Clin Res. 2014;8(2):59-61.

12. Wang L, Oliveira DT, Consolaro A, Perez F. Tratamento de hemangioma bucal com agente esclerosante. Rev Robrac. 1998;24(7):20-22.

13. Zanettini I, Zanettini RM, Gollo G. Escleroterapia como alternativa de tratamento de lesões vasculares bucais. Rev Clin Pesq. 2005;2(2):19-126.

14. Chinen A, Martins R.H, Santos GG, Souza A, Marcucci G. Hemangioma: aspectos clínicos, diagnóstico e terapêutica de 235 casos. Rev Odontol UNICID. 1996;8(1):43-9.

15. Sukigara M, Omoto R, Miyamae T. Systemic dissemination of ethanolamine oleate after injection scleroterapy for esophageal varices. Arch Surg. 1985;120:833-6. http://dx. doi.org/10.1001/archsurg.1985.01390310071016

Received on: 21/1/2020 Final version resubmitted on: 10/2/2020 Approved on: 12/3/2020 